\title{
Speciation and hydrological transport of metals in non-acidic river systems of the Lake Baikal basin: Field data and model predictions
}

\author{
Josefin Thorslund $^{1} \cdot$ Jerker Jarsjö $^{1}$ - Teresia Wällstedt ${ }^{2}$ Carl Magnus Mörth ${ }^{3}$. \\ Mikhail Yu. Lychagin ${ }^{4} \cdot$ Sergey R. Chalov ${ }^{4}$
}

Received: 14 July 2015/Accepted: 2 May 2016/Published online: 6 June 2016

(c) The Author(s) 2016. This article is published with open access at Springerlink.com

\begin{abstract}
The speciation of metals in aqueous systems is central to understanding their mobility, bioavailability, toxicity and fate. Although several geochemical speciation models exist for metals, the equilibrium conditions assumed by many of them may not prevail in field-scale hydrological systems with flowing water. Furthermore, the dominant processes and/or process rates in non-acidic systems might differ from well-studied acidic systems. We here aim to increase knowledge on geochemical processes controlling speciation and transport of metals under nonacidic river conditions. Specifically, we evaluate the predictive capacity of a speciation model to novel measurements of multiple metals and their partitioning, under high$\mathrm{pH}$ conditions in mining zones within the Lake Baikal basin. The mining zones are potential hotspots for increasing metal loads to downstream river systems. Metals released from such upstream regions may be transported all the way to Lake Baikal, where increasing metal contamination of sediments and biota has been reported. Our
\end{abstract}

Electronic supplementary material The online version of this article (doi:10.1007/s10113-016-0982-7) contains supplementary material, which is available to authorized users.

Josefin Thorslund

josefin.thorslund@natgeo.su.se

1 Department of Physical Geography and the Bolin Centre for Climate Research, Stockholm University, 10691 Stockholm, Sweden

2 Department of Applied Environmental Science, Stockholm University, 10691 Stockholm, Sweden

3 Department of Geological Sciences, Stockholm University, 10691 Stockholm, Sweden

4 Faculty of Geography, Lomonosov Moscow State University, Leninskie Gory, 1, Moscow, Russia 119991 results show clear agreement between speciation predictions and field measurements of $\mathrm{Fe}, \mathrm{V}, \mathrm{Pb}$ and $\mathrm{Zn}$, suggesting that the partitioning of these metals mainly was governed by equilibrium geochemistry under the studied conditions. Systematic over-predictions of dissolved $\mathrm{Cr}, \mathrm{Cu}$ and Mo by the model were observed, which might be corrected by improving the adsorption database for hydroxyapatite because that mineral likely controls the solubility of these metals. Additionally, metal complexation by dissolved organic matter is a key parameter that needs continued monitoring in the Lake Baikal basin because dependable predictions could not be made without considering its variability. Finally, our investigation indicates that further model development is needed for accurate As speciation predictions under non-acidic conditions, which is crucial for improved health risk assessments on this contaminant.

Keywords Metals - Speciation - River system · Non-acidic $\cdot$ Geochemical modelling $\cdot$ Lake Baikal

\section{Introduction}

Metals can become exposed to the environment through natural processes, such as the weathering of soil and bedrock, and through anthropogenic processes, such as mining, other industrial activities and agriculture. Metals can enter aqueous systems through washout from surface soils, diffuse groundwater inflow, metal-enriched sediments, leaching from agricultural areas and mine tailings, catastrophic tailings dam failure and the discharge of industrial and mining effluents (e.g. Hudson-Edwards 2003; Macklin et al. 2006; Mighanetara et al. 2009; Inam et al. 2011). Material mobilization via bank and bed erosion under 
conditions of geomorphic adjustment can dominate pollutant transport under certain conditions (Chalov et al. 2015). Due to their non-degradable nature, metals in alluvial stores may pose a threat to ecosystems long after their initial release and alluvial sediments may constitute the greatest source of catchment heavy metal pollution (Alexeevsky et al. 2013).

Mounting evidence has shown that the speciation of metals (i.e. the ability of metals to assume various chemical forms) controls their mobility, bioavailability and toxicity (Tessier and Campbell 1987; Tack and Verloo 1995; Fytianos 2001; Landner 2005). Metal contamination is a recognized problem within the unique ecosystem of Lake Baikal, hosting a wide variety of endemic species and encompassing a huge freshwater resource. There are several potential upstream source zones contributing to the transport of metals downstream towards Lake Baikal, including gold and coal mining areas along the Tuul and Sharyngol Rivers, in Mongolia. With increasing metal accumulation in both sediment and biota being reported in the Lake Baikal waters (Rudneva et al. 2005; Khazheeva et al. 2006), understanding processes controlling metal speciation and fate within this basin is of key significance for managing this ecosystem. For instance, the riverine transport of sorbed or precipitated metals may be significantly retarded relative to metals in dissolved forms (Thorslund et al. 2012; Chalov et al. 2015). However, depending on the geochemical conditions, the processes and process rates that control metal speciation may differ considerably and the relative controls of various geochemical processes in this system are still largely unknown. Additionally, hydrological processes may transport metals to downstream regions with different environmental conditions. Changing environmental conditions within the Lake Baikal basin is still a research area with many unknowns, for example regarding hydroclimatic and permafrost changes (Törnqvist et al. 2014).

To increase the knowledge on metal contamination within this system, there is a need for evaluating the use of speciation models for making dependable predictions of metal speciation and its various controls. Frequently used speciation models include WHAM (Tipping 1994), PHREEQC (Parkhurst and Appelo 1999) and Visual MINTEQ (Gustafsson et al. 2009). Although these models have been shown to provide excellent representation of metal speciation in laboratory environments (e.g. Almås et al. 2007; Caruso et al. 2008), the step from model applicability in small-scale controlled laboratory environments to real field conditions can be challenging. For instance, the equilibrium conditions that can be obtained in the laboratory and that are assumed by many speciation models may not exist in hydrological systems with flowing water. Furthermore, incomplete observational data combined with spatio-temporal heterogeneity in field-scale geochemical conditions may lead to non-representative model assumptions, which in turn can result in errors and systematic biases in model predictions (Destouni et al. 2010; Persson et al. 2011).

For the above reasons, studies assessing model predictions relative to field measurements are needed to test hypotheses regarding field-scale processes. Comparisons between speciation predictions and observations have been made for different metals in various types of natural systems (Butler et al. 2009; Gustafsson et al. 2009; Wällstedt et al. 2010; Nystrand et al. 2012). However, most of these studies have focused on the behaviour of limited number of metals, in acidic waters. Similarly to acidic systems, nonacidic systems also experience various metal pollution problems (Tarras-Wahlberg et al. 2000; Sjöblom et al. 2004; Grosbois et al. 2009). Partly due to fewer field observations, there are open questions regarding dominating processes of metal speciation in non-acidic systems. For instance, depending on processes, absolute concentrations in the dissolved phase that commonly is associated with higher toxicity may or may not become high, even if suspended loads of metals in non-acidic systems frequently are high (Tarras-Wahlberg et al. 2000). Additionally, speciation studies focusing on the large-scale transport of metals in hydrological systems remain rare (Pandey et al. 2014; Sungur et al. 2014). Thus, a relatively large number of combinations of water-metal systems exist that have not been evaluated with regard to model performance. This mismatch causes important knowledge gaps, such as the extent to which and under what conditions metal partitioning in heterogeneous water systems is governed by equilibrium geochemistry and how well state-of-the-art speciation models may perform in these systems.

The overall aims of this study are to (1) identify dominant geochemical controls on the speciation of metals under non-acidic conditions in natural waters and (2) investigate the extent to which geochemical equilibrium processes explain the partitioning of different metals in relatively large river systems in which flowing water potentially causes local to regional non-equilibrium conditions in the governing processes. More specifically, to address these aims and increase the limited number of model-observation comparisons for many metals in natural waters, we evaluate the predictive capacity of a geochemical speciation model (Visual MINTEQ) to regional-scale partitioning observations of 11 metals within the Lake Baikal basin. Evaluating also the fit between model results and field observations under different processes assumptions, we aim to identify dominant geochemical controls that, coupled to hydrological processes, govern the mobility and transport of metals in this non-acidic system. 


\section{Site description}

As applied examples, we consider the Tuul and Sharyngol Rivers, which are both influenced by mining activities and are located in the Mongolian upstream part of the Lake Baikal drainage basin (see Fig. 1, Pietron 2012; Thorslund et al. 2012; Chalov et al. 2012, 2015; Batbayar et al. 2015). The Tuul River encompasses Mongolia's largest placer gold mining site Zaamar Goldfield, and the Sharyngol River is dominated by open-pit coal mining (MCA 2011). The Tuul River basin covers an area of approximately $50,000 \mathrm{~km}^{2}$, and the Sharyngol River basin is approximately half this size (MCA 2011). The activity of the numerous mining companies within the Zaamar Goldfield, along with illegal mining, is considered to have a serious impact on the water quality within the river basin (Altansukh and Davaa 2011; Chalov et al. 2012; Thorslund et al. 2012; Shinkareva et al. 2015) and may have an impact on the downstream Selenga River and Lake Baikal. High levels of metals have been measured in the Tuul River (Lee et al. 2006; AATA 2008), and previous mass balance quantifications have shown a net increase in metal loading, especially of metals in suspension, in the mining zone (Stubblefield et al. 2005; Thorslund et al. 2012).

Both rivers are tributary rivers to the Orkhon-Selenga river system. The transboundary Selenga River is by far the largest river draining into Lake Baikal (Lee et al. 2006), discharging approximately $30 \mathrm{~km}^{3}$ of water and 3.5 million tons of sediments annually into the lake. Before the Selenga River flows into Lake Baikal, it flows through the Selenga delta, which covers an area of approximately $1200 \mathrm{~km}^{2}$ (USGS 2011).

The annual average discharge of the Tuul River is $27 \mathrm{~m}^{3} / \mathrm{s}$ (1945-2007), with maximums of approximately $80 \mathrm{~m}^{3} / \mathrm{s}$ (in the summer). Below the confluence of the Tuul River with the Orkhon River, the discharges increase by an order of magnitude reaching annual average discharges of about $1000 \mathrm{~m}^{3} / \mathrm{s}$ in the downstream Selenga River (GEMStat 2009; MCA 2011). The annual average discharge of the Sharyngol River is much lower than that of the Tuul River, with a long-term average (1977-2007) of only $1.7 \mathrm{~m}^{3} / \mathrm{s}$ (MCA 2011). The regional climate is semiarid with warm and dry summers (average temperatures of $20{ }^{\circ} \mathrm{C}$ ), intense rainfall and cold winters (average temperatures of $-20{ }^{\circ} \mathrm{C}$ ) and annual average temperature of $0.8{ }^{\circ} \mathrm{C}$ and precipitation between 200 and $250 \mathrm{~mm}$, and (AATA 2008).

The geology of the area includes sedimentary, igneous and metamorphic rock formations, such as sedimentary sandstones and siltstones, igneous gabbros and metamorphic schists. The region also naturally contains abundant calcium bicarbonate (Altansukh and Davaa 2011), and there are strong interactions between the surface waters and groundwater due to extensive areas of alluvial unconfined aquifers in the river valleys (Zandaryaa et al. 2008). This condition impacts the quality and quantity of both the Tuul and Sharyngol Rivers because the rivers are fed by groundwater inflows with high degrees of water-rock interaction, causing high $\mathrm{pH}$ values throughout the region (Lee et al. 2006; Zandaryaa et al. 2008).

\section{Methods}

\section{Field sampling and analysis}

Water samples for metal analyses were collected during two field campaigns, one in June 2012 and one in September 2013. In the first year, five locations in the vicinity of the Zaamar Goldfield along the Tuul River (T5, T5a, T5b, T6 and T6a) were sampled. In addition to the same five locations near the Zaamar Goldfield, 12 new locations were sampled in the study region in 2013: five along the Tuul River (T2, T3, T4, T6b and T7), four along the Sharyngol River (S1, S2, S3 and S5) and three waste water ponds at the Zaamar site (P1, P3 and P4). pH and alkalinity were also measured, directly in the rivers and ponds, at all sampling locations during both years. In addition to the water samples for metal analysis, total and dissolved organic carbon (TOC and DOC) samples were collected from all the locations in the 2013 campaign. The sampling locations are shown in Fig. 1, and further details regarding sampling and analysis procedures are given in supplementary information (S1).

\section{Discharge measurements and mass flow estimates}

Discharge was estimated at five cross sections along the Tuul River (T5, T5a, T5b, T6 and T6a), in the vicinity of the Zaamar Goldfield, in both 2012 and 2013. Simultaneous measurements of water samples for metal concentration analyses and discharges were made to obtain snapshot values of the loads along the river reach and across the Zaamar mining site. Details on discharge calculations and mass flows for the cross sections are given in supplementary information (S2).

Relatively low water discharges were observed during the June 2012 campaign $\left(Q=13-15 \mathrm{~m}^{3} / \mathrm{s}\right)$, whereas substantial flooding with floodplain inundation was documented during the September 2013 field campaign $\left(Q=45-52 \mathrm{~m}^{3} / \mathrm{s}\right)$. The hydrometeorological conditions also varied between the seasons, e.g. relatively dry weather during the 2012 campaign and abundant rainfall in the 2013 campaign. 


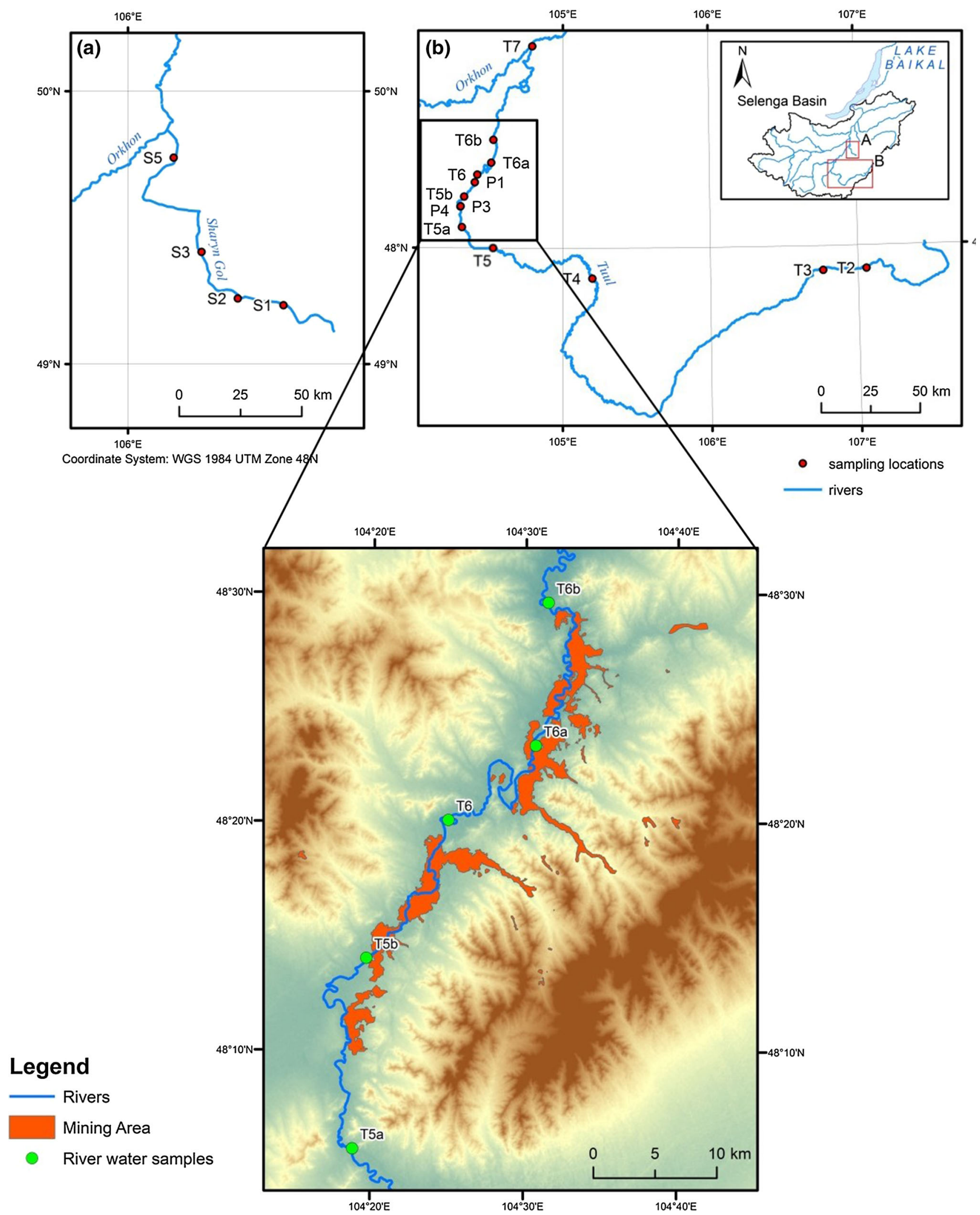

Fig. 1 Map showing the two sampled rivers, the Tuul River (a) and the Sharyngol River (b), within the Lake Baikal basin. The zoomed map indicates the locations of the Zaamar mining area along the Tuul River, the sampled ponds and other mining areas (author: J. Pietron) 


\section{Modelling approach}

The geochemical equilibrium model Visual MINTEQ version 3.0 (Gustafsson 2010) was used to model the speciation of the following eleven selected metals: Al, As, $\mathrm{Cd}, \mathrm{Cr}, \mathrm{Cu}, \mathrm{Fe}, \mathrm{Mn}, \mathrm{Mo}, \mathrm{Pb}, \mathrm{V}$ and $\mathrm{Zn}$. This model calculates the chemical compositions of various inorganic ions in aqueous systems at a single point (in our case a water sample) under the assumption of chemical equilibrium. For inorganic complexes, the thermodynamic default database in Visual MINTEQ was used, which is primarily based on the National Institute of Standards and Technology (NIST) compilation (Smith et al. 2003).

Complexation of the metals with DOC was modelled using the 'Stockholm humic model' (SHM) (Gustafsson et al. 2014) with its default database. The DOC and major anions were not measured during the field campaign in 2012. Thus, when modelling the 2012 data, the DOC values from the 2013 campaign were used. In addition, scenario simulations involving DOC values $50 \%$ higher than the site-specific values and absent DOC values were used for all the locations to investigate the sensitivity to changing DOC concentrations.

The solids that were allowed to precipitate when their respective solubility constants were exceeded are given in Table S4. These solids were chosen based on (1) knowledge of common solids for the present geological conditions of the study site and (2) the model outputs of 'saturation indices', which indicate the minerals likely to precipitate based on site-specific data and thermodynamic calculations. Ferrihydrite and gibbsite were chosen as possible solids for sorption reactions, due to their high measured particulate concentrations and sorption capacities. Sorption was estimated using the diffuse layer model (DLM) using the default database in Visual MINTEQ based on Dzombak and Morel (1990) and Karamalidis and Dzombak (2010) for ferrihydrite and gibbsite, respectively. The only exception was vanadate adsorption to ferrihydrite, for which the adsorption constants were changed based on Wällstedt et al. (2010). For more detailed description of the modelling parameters, procedure and assumptions, please see supplementary information (S3).

\section{Correlation analysis}

Given that the dissolution of metals increases their mobility and bioavailability, we tested the extent to which the dissolved metal fraction can be predicted based on the total concentrations under the assumption of equilibrium partitioning between the dissolved and suspended phases. This test was performed by evaluating the extent to which the results of the applied chemical equilibrium model agree with the observations. Specifically, we performed linear correlation analyses between the measured and modelled dissolved metal fractions for each metal and year (see "Comparing observations and model predictions" section). The coefficient of determination $\left(r^{2}\right)$ was calculated for each metal, along with the average ratio between the modelled and measured dissolved fractions. Ratios greater than unity indicate systematic over-predictions, and ratios less than unity indicate under-predictions.

\section{Results}

\section{Water chemistry}

The geochemical measurements of all sampling locations along the Tuul River, the Sharyngol River and ponds show average $\mathrm{pH}$ conditions of 8.3 (Tuul), 8.2 (Sharyngol) and 8.7 (ponds), which indicate alkaline conditions throughout the sampled system. DOC concentrations are similar for all the sampled locations, with slightly higher average values for the Sharyngol River (10.7) than for the Tuul River $(10.4 \mathrm{mg} / \mathrm{l})$ and the ponds $(9.6 \mathrm{mg} / \mathrm{l})$. The TOC concentrations averaged only a few per cent higher than the DOC concentrations; hence, DOC dominates the total organic matter composition. The estimated alkalinity values are very high (up to $8.5 \mathrm{meq} / \mathrm{l}$ ) especially from the field measurements in 2013. For detailed geochemical results for each sampling location (used as model input), see supplementary information (Table S3).

The dissolved and total riverine concentrations for the reach of the Tuul River that was sampled in both years (T5, T5a, T5b, T6 and T6a) are shown in Fig. 2a-k. These sites represent upstream, at site and downstream locations relative to the Zaamar Goldfield. Total concentrations of Al, $\mathrm{As}, \mathrm{Cd}, \mathrm{Cr}, \mathrm{Cu}, \mathrm{Fe}, \mathrm{Mn}, \mathrm{Pb}$ and $\mathrm{V}$ show net increases across the site, with higher values in the most downstream point (T6a) compared to the upstream points (T5, T5a). The differences between the particulate and dissolved concentrations are greatest for $\mathrm{Al}, \mathrm{Fe}$ and $\mathrm{Mn}$, with particulate concentrations that average 178, 35 and 25 times greater, respectively, than the dissolved concentrations in the 2012 campaign and 42, 18 and 5 times greater, respectively, in the 2013 campaign. As, $\mathrm{Cd}, \mathrm{Cr}, \mathrm{Cu}$ and Mo have dissolved concentrations of the same order of magnitude as their total concentrations. $\mathrm{V}$ and $\mathrm{Zn}$ show varying behaviours, exhibiting both higher dissolved and particulate concentrations depending on the sampling point.

Several metals (Al, As, Fe and Mn) show total (unfiltered) concentrations that exceed the World Health Organization (WHO 2006) and Mongolian health risk-based guideline values (Table S3). As even exhibits dissolved (filtered) concentrations that exceed these health risk-based guideline values. Furthermore, a comparison of the 
Fig. 2 Dissolved (blue) and total (red) concentrations of investigated metals at the sampling locations along the Tuul River from the 2012 (squares) and 2013 (circles) campaigns. When no results were detected, the midpoint of the possible concentration range is shown in a lighter colour (see SI for DL values) (colour figure online)

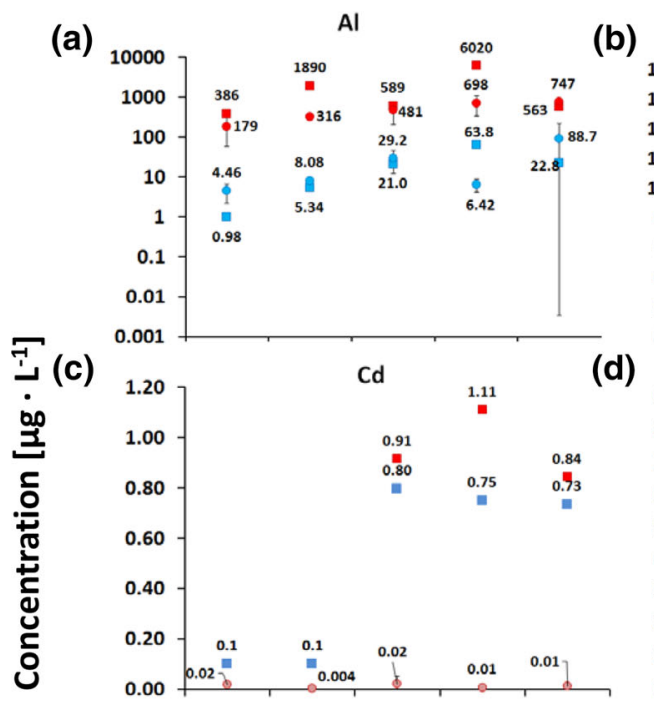

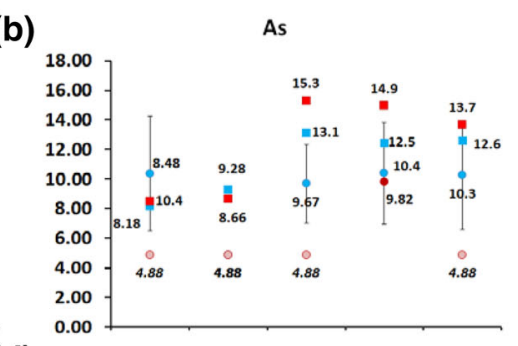

(e)

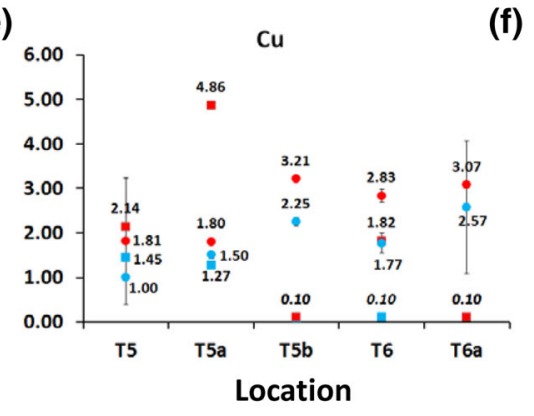

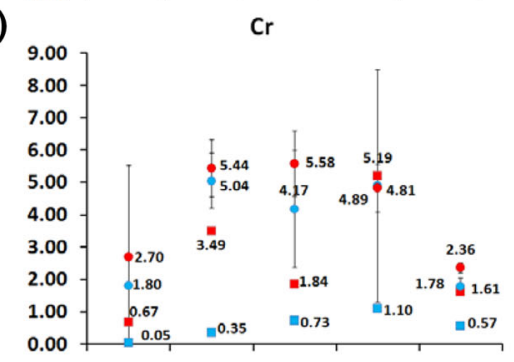

(g)

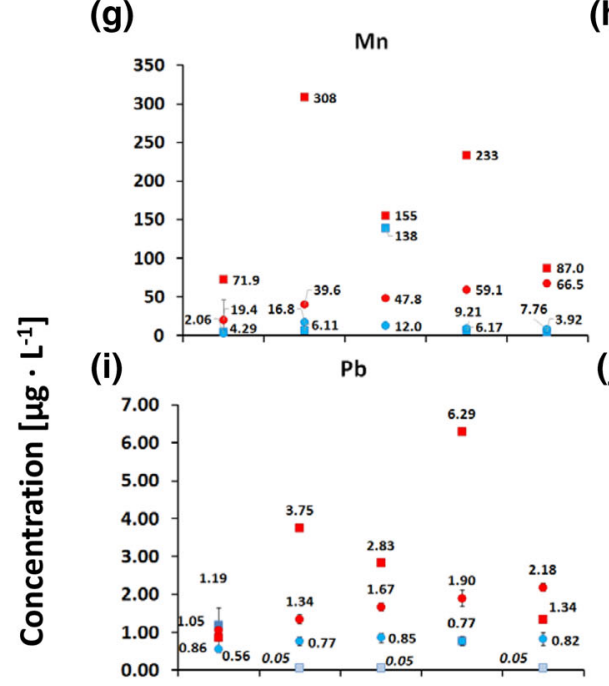

(h)

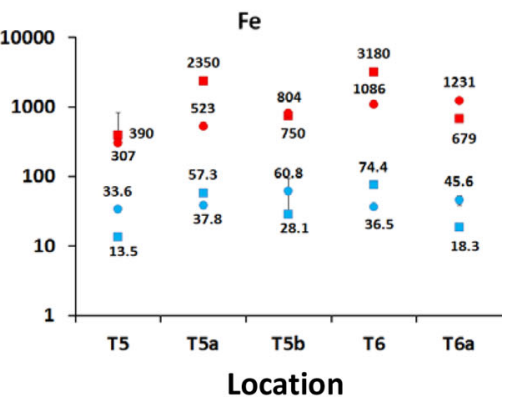

(k)

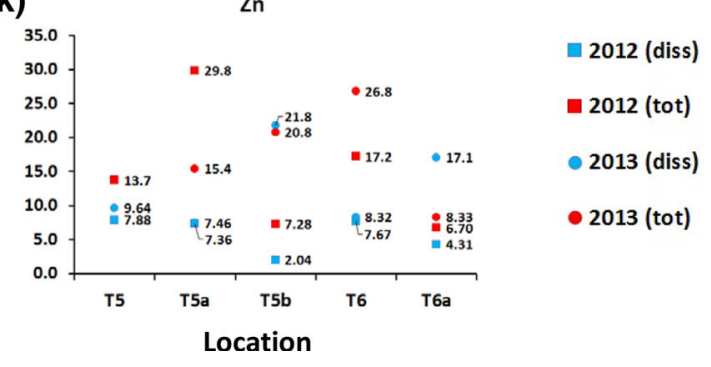


monthly average concentration data for the Tuul River during the summer or autumn months of 2005, 2006 and 2008 indicates that the concentrations can be even higher in this system (Thorslund et al. 2012) than those observed during the 2012 and 2013 campaigns.

\section{Riverine mass flows}

A general result from our mass flow estimations (see S2), in line with the concentration trends, is that the majority of metals from both campaign years show net increases in total mass flows across the Zaamar Goldfield, with higher values at the farthest downstream point (T6a) than the farthest upstream points (T5, T5a). Due to the previously noted large dissolved and total concentration differences, the differences between the dissolved and total mass flows are generally high, with total mass flows up to two orders of magnitude higher than the dissolved mass flows, especially for $\mathrm{Al}, \mathrm{Fe}$ and $\mathrm{Mn}$. In contrast, the dissolved mass flows of $\mathrm{As}, \mathrm{Cd}, \mathrm{Cr}, \mathrm{Cu}$ and Mo are generally of the same magnitude as the total mass flows. The total mass flows of most metals (As, $\mathrm{Cr}, \mathrm{Cu}, \mathrm{Fe}, \mathrm{Mo}, \mathrm{Pb}, \mathrm{V}$ and $\mathrm{Zn}$ ) were higher in the 2013 campaign than in the 2012 campaign (median: five times higher). Furthermore, previously quantified mass flows of metals at the same locations during the summer or autumn months of 2005, 2006 and 2008 commonly exhibited even higher mass flows than during the present 2013 campaign (Thorslund et al. 2012).

\section{Model results}

\section{Comparing observations and model predictions}

Figure 3 shows a comparison between the measured and modelled results of the dissolved metal fractions (percentages) for the considered sampling locations in the (a) 2013 and (b) 2012 campaign. On average, the correlations between the predictions and measurements are stronger for the 2013 dataset than for the 2012 dataset (see Table S6 for all metal-specific correlation coefficients values). In addition, the regression analyses showed significant correlation for seven metals ( $\mathrm{Al}, \mathrm{As}, \mathrm{Cd}, \mathrm{Fe}, \mathrm{Pb}, \mathrm{V}$ and $\mathrm{Zn}$ ) in 2013, compared to three cases in 2012 (As, V and $\mathrm{Zn}$ ), which is likely due to the higher number of data points in 2013. In the following discussion, the main focus is on the significant regression results. Nevertheless, comparing the ratio of the modelled and measured dissolved fractions (Rf) between the 2 years, the general patterns (over- or under-predicted) are mostly consistent between 2012 and 2013 (Table S6).

Based on the comparisons of the model predictions to the measurements, the metals from the 2013 dataset can be grouped into three categories. The metals in the first group,
(1) $\mathrm{Fe}, \mathrm{Pb}, \mathrm{Zn}$ and $\mathrm{V}$, featured strong correlations between the modelled and measured results $\left(0.45 \leq r^{2} \leq 0.82\right.$, $p<0.05)$, and all had $\mathrm{Rf}$ values close to unity $(0.8 \leq \mathrm{Rf} \leq 1.2)$. Fe had the overall best correlation between the modelled and measured results $\left(r^{2}=0.82\right.$, $p<0.05, \mathrm{Rf}=0.81)$. Thus, the model can adequately explain the variability in the measurements for these four metals, suggesting that the partitioning of these metals is strongly influenced by equilibrium geochemistry. We can thus further use this model approach for detailed speciation predictions of these metals to identify the main processes governing their speciation (see "Detailed speciation of metals governed by equilibrium processes" section). For 2012, a different pattern was observed with weak correlations between $\mathrm{V}$ and $\mathrm{Zn}$; however, as discussed below ("Metals governed by equilibrium processes" section), these results are likely related to the measurements rather than the model.

The predictions for the metals in the second group, (2) $\mathrm{Al}$ and $\mathrm{As}$, featured weak correlations with the measurements $\left(r^{2}=0.15\right.$ and 0.25 , respectively, $\left.p<0.05\right)$ and $\mathrm{Rf}$ values that differed significantly from unity. The dissolved Al was constantly under-predicted by the model relative to the measurements, as demonstrated by its Rf (0.2). As had an Rf close to unity (1.03), however, individual data points exhibited relatively large deviations from this mean ratio. The weak correlations for both $\mathrm{Al}$ and As may be due to non-represented equilibrium processes, inaccurate equilibrium constants, the influence of non-equilibrium processes or a combination of these factors. It might also be related to simplifying model assumptions about gibbsite being the only precipitate of $\mathrm{Al}$, neglecting for instance a possible presence of colloidal clay particles.

The metals in the third group, (3) $\mathrm{Cr}, \mathrm{Cu}, \mathrm{Mn}$ and $\mathrm{Mo}$, all had constant model outputs for the full range of the measured input data, i.e. the model was not sensitive to changing measured fractions. Therefore, these metals are governed either by non-represented equilibrium processes, non-equilibrium processes or a combination of both. Due to the static model output for these metals, they are excluded from Fig. 3 but are discussed further below.

\section{Detailed speciation of metals governed by equilibrium processes}

From the strong correlations between modelled and measured dissolved fractions in the 2013 dataset, the metals in the first category $(\mathrm{Fe}, \mathrm{Pb}, \mathrm{V}$ and $\mathrm{Zn}$ ) were mainly governed by equilibrium processes. For the metals in the second category ( $\mathrm{Al}$ and $\mathrm{As}$ ), although weak, there was a correlation between the model predictions and the measurements, indicating that equilibrium processes can explain the variability in measured fractions to some extent. The 

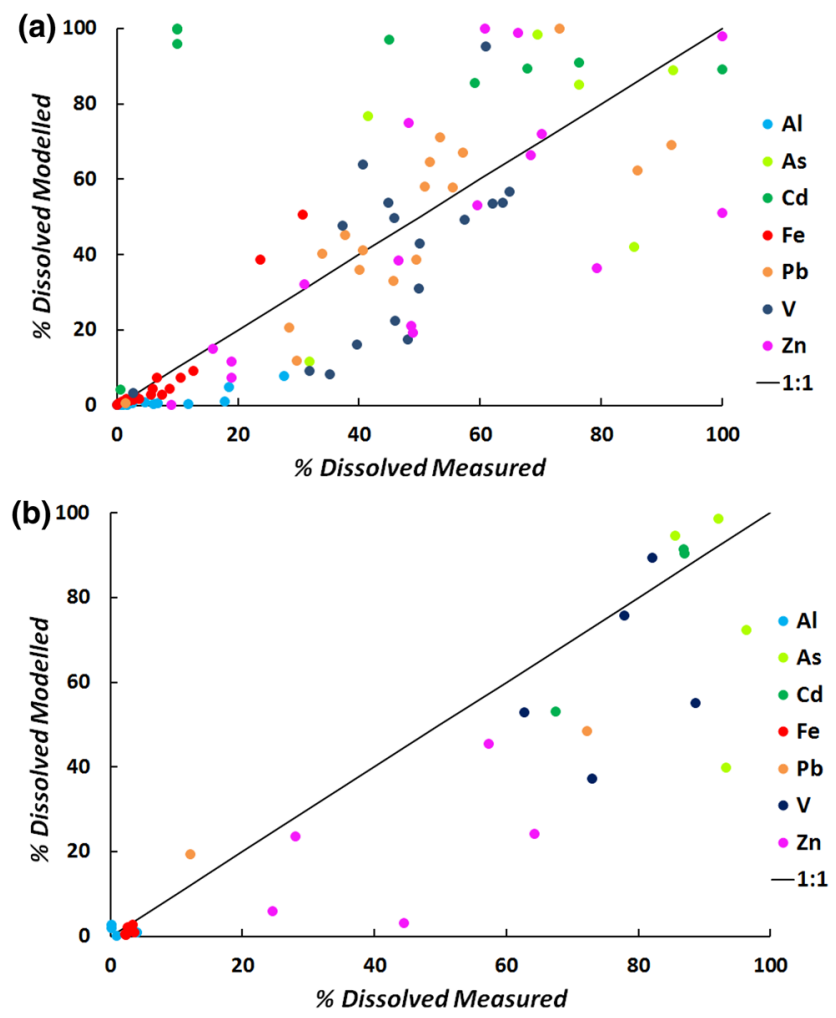

Fig. 3 Comparison between the measured and modelled results for the dissolved fractions (percentage) of metals in a the 2013 campaign and $\mathbf{b}$ the 2012 campaign

detailed modelling results that show the key processes governing these metals speciation are shown in Fig. 4. The sum of the modelled fractions; 'dissolved inorganic' and 'bound to DOM' corresponds to the measured 'dissolved' fraction (filtered samples), whereas the modelled 'sorbed' and 'precipitated' fractions correspond to the measured 'total' fraction (unfiltered samples). As seen here, the precipitation of gibbsite and ferrihydrite was predicted to be the dominant control of $\mathrm{Al}$ and $\mathrm{Fe}$, with these particulate fractions generally limiting their solubility by $90-100 \%$. The only exceptions to these results were the predictions for the most upstream Tuul River locations (T2 and T3, see Fig. 4), where 40-50\% was predicted to occur as soluble organic complexes (bound to DOC). In the other locations, only minor fractions of $\mathrm{Fe}$ (up to $10 \%$ ) were predicted to exist as complexes with organic matter. We identify $\mathrm{pH}$ as the primary parameter controlling this difference (the $\mathrm{pH}$ is lowest at the upstream locations) because all the other parameters were similar.

Sorption processes to ferrihydrite and gibbsite mainly controlled the solubility of $\mathrm{V}, \mathrm{Pb}$ and $\mathrm{Zn} . \mathrm{V}$ and $\mathrm{Pb}$ were predicted to sorb only to ferrihydrite, on average by $60 \%$. $\mathrm{Zn}$ was predicted to sorb both to ferrihydrite and gibbsite (on average by $65 \%$ ), but with predominant sorption to gibbsite over ferrihydrite (under $\mathrm{pH}$ conditions above 8 ).
The overall highest sorbed fractions for these metals were predicted for the Sharyngol River and the ponds, with pond P4 exhibiting the highest sorption (90-100\%). Contrasting cases of low sorbed fractions and high dissolved fractions of $\mathrm{V}, \mathrm{Pb}$ and $\mathrm{Zn}$ include one of the ponds (P1) and the most upstream Tuul River locations (T2 and T3). As was predicted to mainly occur in its dissolved inorganic fraction, but with some sorption to ferrihydrite as well, especially in the ponds (P3, P4).

Metal-organic complexation also had a large impact on the speciation of $\mathrm{Pb}$ and $\mathrm{Zn}$. These metals were predicted to form soluble complexes with DOC, on average governing their speciation by 50 and $30 \%$, respectively. Furthermore, a model scenario where DOC concentrations were increased by $50 \%$ to investigate the influence of parameter uncertainty showed that the dissolved fractions were then predicted to be higher for all the investigated metals. The greatest impacts were on the $\mathrm{Fe}, \mathrm{Pb}$ and $\mathrm{Zn}$ solubilities, which on average increased by 65,40 and $30 \%$, respectively. Scenario simulations without considering DOC were also conducted for five locations along the Tuul River (T2, T3, T4, T6b and T7). The lack of DOC data decreased the agreement between the measured and modelled results for $\mathrm{V}$ and $\mathrm{Pb}$. When DOC was considered, the differences between the measured and modelled dissolved fractions were low, on average 9 and $3 \%$ for $\mathrm{V}$ and $\mathrm{Pb}$, respectively. Without accounting for DOC in the model, these differences increased to $28 \%(\mathrm{~V})$ and $53 \%(\mathrm{~Pb})$.

\section{Discussion}

\section{Metals governed by equilibrium processes}

As shown in the previous section, the observed speciation of $\mathrm{Fe}, \mathrm{Pb}, \mathrm{V}$ and $\mathrm{Zn}$ in the Tuul River was robustly predicted with the chosen equilibrium model approach and considered processes (including the sorption to ferrihydrite and gibbsite, and complexation to organic matter). Both $\mathrm{Fe}$ and $\mathrm{Pb}$ modelling have been shown by others to produce robust predictions that agree well with measurements in several types of river systems, including acidic (e.g. Tonkin et al. 2002; Wällstedt et al. 2010; Nystrand et al. 2012) and non-acidic conditions (e.g. Tonkin et al. 2002; SanchesEspana et al. 2006; Balistrieri et al. 2007; Hayzoun et al. 2015). The present results further support the use of equilibrium models to predict the behaviours of $\mathrm{Fe}$ and $\mathrm{Pb}$ under a relatively wide range of geochemical conditions, including the high-pH conditions of our modelled river system.

Under high-pH conditions, sorption processes can have a large influence on metal solubility, with important consequences on their transport and fate in natural systems 


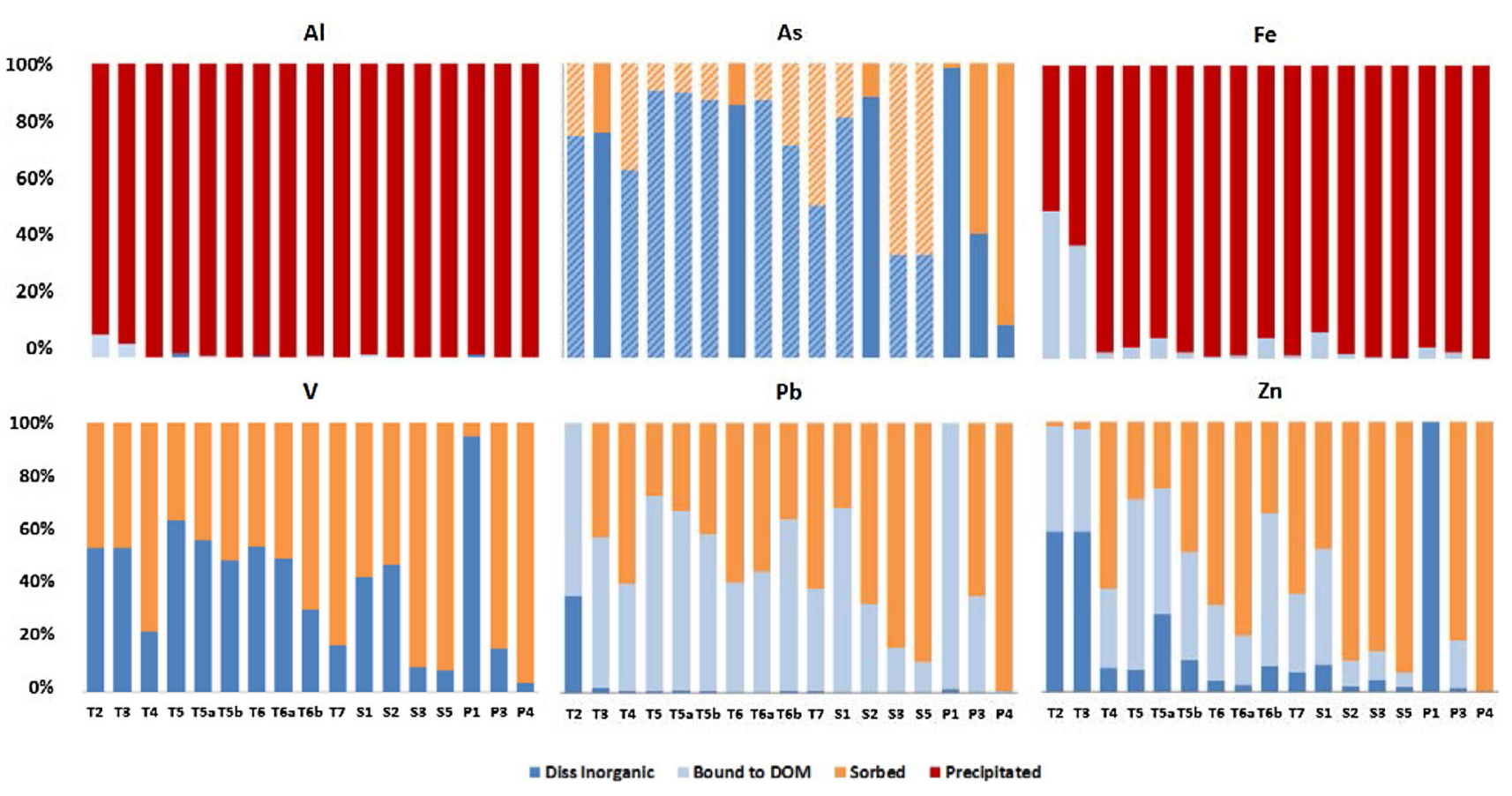

Fig. 4 Detailed modelled speciation ('dissolved inorganic', 'bound to DOM', 'sorbed' or 'precipitated') of the metals governed by geochemical equilibrium in the 2013 campaign. Striped columns indicate that measured concentrations $<\mathrm{DL}$

(e.g. Zhao et al. 2011). Pb has previously been shown to have high sorption to ferrihydrite at circum-neutral $\mathrm{pH}$ values. For example, using measurement data and PHREEQC speciation modelling, Sanches-Espana et al. (2006) demonstrated that $90-99 \%$ of available $\mathrm{Pb}$ was sorbed to ferrihydrite within the $\mathrm{pH}$ range $7-8$. Moreover, model predictions made by Jung et al. (2005) showed $95 \%$ of $\mathrm{Pb}$ was adsorbed onto ferrihydrite at $\mathrm{pH} 7$. With the current data-supported predictions, we show that sorption to ferrihydrite is an important process in river systems at even higher $\mathrm{pH}$ values, with over $70 \%$ of $\mathrm{Pb}$ adsorbed onto ferrihydrite at $\mathrm{pH}>8$. For $\mathrm{V}$, our results show the same (over $70 \%$ ) amount of sorption to ferrihydrite at $\mathrm{pH}>8$; similar values were previously only identified in acidic to neutral pH river systems (Wällstedt et al. 2010). The dissolved fractions of $\mathrm{Pb}$ and $\mathrm{V}$ are under-predicted in the model to a similar extent as dissolved Fe (Table S4). These dissolved under-predictions occur because the modelled sorption of $\mathrm{Pb}$ and $\mathrm{V}$ to ferrihydrite is slightly over-predicted; according to the model, more Fe is in the precipitated ferrihydrite phase and less is in the dissolved phase relative to the measurements.

Our predictions indicate that sorption to both gibbsite and ferrihydrite is important for controlling $\mathrm{Zn}$ solubility. The general over-prediction of non-dissolved $\mathrm{Al}$ (see "Comparing observations and model predictions" section) may indicate that fewer gibbsite surfaces are available for sorption in our system than the model suggests. However, both the model results and measurements agree on the high suspended concentrations of $\mathrm{Al}$ and $\mathrm{Fe}$, suggesting that both precipitates are important for $\mathrm{Zn}$ sorption at the investigated $\mathrm{pH}$ range. This contrasts with the reported results for lower $\mathrm{pH}$ ranges, where ferrihydrite alone controlled Zn sorption (Jung et al. 2005; Wällstedt et al. 2010).

Organic matter was also shown by our data-supported predictions to have a large impact on metal speciation in non-acidic systems. This effect is related to the negative charge on the humic molecules, which enhances the complexation capacity for positively charged metal ions (e.g. Ahmed et al. 2014). Many studies (e.g. Christensen et al. 1996; Hagedorn et al. 2000; Sauvé et al. 2000) have suggested that organic matter is an important parameter that governs the transport and fate of metals in natural systems. More specifically, a modelling approach by Weng et al. (2002) showed that complexation with organic matter could lead to dissolved concentrations of $\mathrm{Pb}$ up to two orders of magnitude greater than those without DOC, especially in alkaline conditions, and could produce significant effects on the solubility of $\mathrm{Zn}$. Antoniadis and Alloway (2002) also found that complexation with DOC significantly increased the dissolved concentrations of $\mathrm{Zn}$. These findings are consistent with the fact that our model's performance for the considered high-pH system decreased drastically when the DOC measured in 2013 was not included. Analogously, in the absence of DOC data for 2012, the correlations between the model results and measurements for $\mathrm{V}$ and $\mathrm{Zn}$ are lower (Fig. 4a) than those in 2013, when DOC data are available. The absence of this 
parameter in most field sampling datasets (Caruso et al. 2008) may greatly increase the prediction uncertainties associated with the transport and fate of metals. Several studies (Schelker et al. 2012; Raymond and Saiers 2010) have shown that DOC concentrations can fluctuate up to several hundreds of per cent due to land use changes (e.g. deforestation), storm events and seasonal variability.

Additionally, our results demonstrate that for the model scenario when DOC concentrations were increased by $50 \%, \mathrm{Fe}-$ organic soluble complexes also increased by between 50 and $80 \%$. This change, in turn, increased the dissolved inorganic fraction of metals previously sorbed to ferrihydrite because the amount of ferrihydrite available for sorption decreased. Hence, this type of competition between minerals, organic matter and dissolved metals may govern the solubility of metals in natural systems, as shown by Tipping et al. (2002).

\section{Metals showing weak correlations between predictions and measurements}

The presented model results for both $\mathrm{Al}$ and As (Table S4) showed weak correlations with the measurements. In contrast, certain model studies for Al have found good correlations with the measured concentrations (Cory et al. 2007; Sjöstedt et al. 2010; Nystrand et al. 2012), but only under acidic $\mathrm{pH}$ conditions. Previous reports of weak modelmeasurement correlations have mainly focused on systems characterized by low dissolved concentrations (e.g. Cory et al. 2007). Similarly, the weak model performance reported here for the fraction of dissolved $\mathrm{Al}$ involved conditions of low absolute dissolved $\mathrm{Al}$ concentrations.

Arsenic is known to be largely represented by dissolved fractions under alkaline conditions (e.g. Early 1999), especially in non-humid climates (Smedley and Kinniburgh 2002), consistent with our case. Furthermore, based on a modelling approach similar to ours, Wällstedt et al. (2010) suggested that the dissolved fraction dominates As speciation in streams with circum-neutral $\mathrm{pH}$. Also, ultrafiltration results demonstrate that under circumneutral $\mathrm{pH}$ conditions As occurs mainly in the dissolved fraction $(<1 \mathrm{kDa})$ and only to a minor extent as colloids/particles (Yu et al. 2016). In our study, As was also predicted to predominantly occur in its dissolved fraction (inorganic) under higher $\mathrm{pH}$ conditions (8.8). However, the model could not readily explain the variability in the measured dissolved fractions $\left(r^{2}=0.25\right)$. This poor correlation is consistent with previously reported weak correlations between measurements and predictions in nonacidic river systems (Raposo et al. 2004). Even in wellinvestigated acidic systems, reproducing As measurements is more difficult than other metals (e.g. Tonkin et al. 2002; Wällstedt et al. 2010; Nystrand et al. 2012). This difficulty may arise from this metal's complex and potentially multiple interactions with oxides and humic materials (e.g. Gustafsson and Bhattacharya 2007), which, in turn, may vary with both the hydrodynamic and geochemical conditions.

Dissolved As concentrations measured here were often greater than the WHO's health risk-based guideline values. Similarly, recent papers on metal contamination in Mongolia (Hofmann et al. 2015; Pfeiffer et al. 2015) have reported high measured dissolved As concentrations under high-pH conditions, including locations in other gold mining regions. From a health risk perspective, there is a need to robustly predict the potential future changes in the bioavailable dissolved fractions under changing ambient conditions. However, the current results emphasize that the existing As models must be further improved to fulfil this need.

\section{Metals exhibiting no correlation between predictions and measurements}

Model results showed invariable fractions of $\mathrm{Cr}, \mathrm{Cu}, \mathrm{Mn}$ and Mo (Table S4) over the whole range of input conditions, which is inconsistent with the measured variability in the dissolved metal fractions. The dissolved Mn fractions were constantly under-predicted by the model (i.e. predicted $100 \%$ precipitation of the mineral manganite).

This under-prediction may be related to $\mathrm{Mn}$ 's wide range of possible oxidation states (Chriswell and Mokhtar 1986), the range of permitted minerals for precipitation, the lack of accurate surface complexation constants or a combination of these factors. Tonkin et al. (2004) also reported difficulties related to obtaining good speciation predictions of Mn compared to observed data.

The rest of the metals in this group $(\mathrm{Cr}, \mathrm{Cu}$ and $\mathrm{Mo})$ were constantly over-predicted with regard to their dissolved fractions. This over-prediction may be explained by sorption onto precipitates in the studied natural river system not accounted for in the current model. Potential precipitates could include apatites, a group of phosphate minerals. These minerals have commonly been suggested to be main solids limiting the dissolved forms of several metals in natural systems (e.g. Chen et al. 2010). Notably, hydroxyapatite, which is a natural calcium phosphate mineral within the apatite group, may be an important solid for sorption in our study region. The measured concentrations of particulate calcium and phosphorous in 2013, which are chemical constituents of the mineral, were considerable in the Tuul River (average concentrations of 25.000 and $87 \mu \mathrm{g} / \mathrm{l}$, respectively), suggesting that the mineral may be present in the system. In addition, the mineral was over-saturated (i.e. if added, it would precipitate as a possible solid phase) in all of the modelled 
locations. Several previous studies (Feng et al. 2010; Gandhi et al. 2011; Asgari et al. 2012; Corami et al. 2008; Bazargan-Lari et al. 2014) have noted the importance of this solid for the adsorption of metals, including $\mathrm{Cr}, \mathrm{Cu}$ and Mo. For example, the adsorption of $\mathrm{Cr}$ to hydroxyapatite was shown experimentally by Asgari et al. (2012) to remove high fractions of dissolved $\mathrm{Cr}$ under $\mathrm{pH}$ conditions of up to 11 . Hence, hydroxyapatite may serve as an active control on several metals, including $\mathrm{Cr}, \mathrm{Cu}$ and $\mathrm{Mo}$, in nonacidic systems. However, this mineral presently cannot be added to the model as a possible solid for adsorption due to the current lack of an adsorption database for this phase.

\section{Impact of metal speciation on hydrological transport}

Out of several branches of the Selenga river in the Mongolian part of the Lake Baikal drainage basin, the Tuul River has been shown to be the largest contributor of suspended sediments to downstream regions, under both high and low flow conditions (Lychagin et al. 2016; Stubblefield et al. 2005). Our here estimated mass flows and parallel quantifications (Jarsjö et al. 2016; Chalov et al. 2016) of metal transport in the Tuul River all point to mining activities as the main driver of increasing sediment loads to downstream regions. Coupled to this, geochemical processes (e.g. sorption) influence the extent to which certain physical processes, such as suspended sediment transport (Stubblefield et al. 2005; Chalov et al. 2012), will govern the overall transport of metals. The precipitation and sorption processes that govern $\mathrm{Al}, \mathrm{Fe}, \mathrm{Pb}, \mathrm{V}$ and $\mathrm{Zn}$ solubility in our model results provide an explanation for an independent quantification of the dominance of heavy metal mass flows in the suspended phase relative to the total riverine mass flows. The potential capacity of sediments to hold a higher mass of metals than a corresponding volume of water is well known (e.g. Horowitz 1991). For the investigated system (and potentially non-acidic mining systems in general), the combined effects of mining activities that stir up metal-rich bottom sediments and the non-acidic environment, which cause the precipitation of $\mathrm{Al}$ and $\mathrm{Fe}$ and enhance the adsorption of several other metals, can lead to a large export of multiple metals in suspension from the site. This scenario is consistent with previous site assessments (Thorslund et al. 2012), suggesting a net contribution of metal loads transported from the Zaamar Goldfield compared to natural mass flows. Because the concentrations of the metals did not vary as much as the discharges, the discharge is the primary factor controlling the magnitude of the mass flows, which is in line with previous studies (Österholm and Åstrom 2008; Basu et al. 2010).

The combined influences of land use alterations (the expansion of mining areas) and projected climate changes (the expected increased frequency of peak flow events; Altansukh and Davaa 2011; Törnqvist et al. 2014) will likely result in increased discharge and erosion in the Lake Baikal drainage basin. Therefore, the transport of metals from the Zaamar site to the connected river systems will also likely increase. The potential for metal release from enriched particles in suspension to the surrounding water, which generally increases metal bioavailability (LourinoCabana et al. 2011), is important to assess further. Such metal dissolution could occur due to changes in ambient conditions for several reasons. For instance, as mentioned previously, DOC may vary considerably in time and space and could increase metal solubility through metal-organic complexation. Specifically, increasing organic matter concentrations have been found to correlate with increased discharges (e.g. Lewis and Grant 1979). These findings highlights the need for further studies assessing the largescale implications of both hydrodynamic processes (which govern the magnitude of suspended sediment transport) and geochemical processes (which govern the mobility of metals between the sediment and water phases), which are critical for appropriate transboundary management of Lake Baikal's local to regional water resources (Karthe et al. 2015).

\section{Conclusions}

Under studied non-acidic conditions of the Tuul River, riverine suspended mass flows constituted the dominant portion of the total mass flows. There was an export of several metals ( $\mathrm{Al}, \mathrm{Cd}, \mathrm{Fe}, \mathrm{Mn}, \mathrm{Pb}$ and $\mathrm{V}$ ) from the site to the downstream river system, as shown by net increasing mass flows across the mining site. Further, most metals had low dissolved concentrations compared to the total measured concentrations, which differs significantly from the distribution of metals in acidic mining environments.

Precipitation and sorption processes explain the high measured prevalence of several metals in suspension. More specifically, data-supported model predictions indicate that the precipitation of ferrihydrite and the associated sorption of $\mathrm{V}$ and $\mathrm{Pb}$ were the main processes limiting the solubility of $\mathrm{Fe}, \mathrm{V}$ and $\mathrm{Pb}$, whereas for $\mathrm{Zn}$, sorption to gibbsite and ferrihydrite were both important. The high correlations between the measurements and equilibrium model results for the dissolved fractions of these metals indicate that these metals are governed by equilibrium geochemistry under the studied conditions, which support the validity of using equilibrium-based speciation models for speciation predictions in non-acidic river systems.

The results demonstrate that the solubilities of $\mathrm{Fe}, \mathrm{Pb}$ and $\mathrm{Zn}$ increase considerably $(80 \%)$ in a model scenario where DOC concentrations were increased by $50 \%$. For 
the studied river system, good model predictions could not be obtained without considering DOC. Since DOC concentrations can fluctuate up to several hundred per cent due to land use changes (e.g. deforestation), storm events and seasonal variability, this highlights the need for continued monitoring of DOC at different spatio-temporal scales, for refined predictive capacity of future studies. Increasing predictive capabilities of dynamic DOC behaviour could also contribute to improving predictions of future metal transport and fate in this non-acidic region.

The model predictions were only weakly correlated with the measurement results for $\mathrm{Al}$ and As under the investigated conditions. These poor correlations may have several causes, for example the influence of other particular forms of $\mathrm{Al}$, such as clay particles, which were currently nonrepresented in the model, other equilibrium processes or inaccurate equilibrium constants, the influence of nonequilibrium processes or a combination. More detailed studies would need to be performed for these metals for dependable predictions in non-acidic river systems, especially for As, sine reported dissolved concentrations measured in the Tuul River exceeded the WHO's health riskbased guideline values. From a health risk perspective, predicting potential future changes in the bioavailable dissolved fractions under changing ambient conditions is particularly important.

The considered equilibrium model consistently overpredicted the dissolved fractions of $\mathrm{Cr}, \mathrm{Cu}$ and Mo relative to the measurements. We suggest that sorption to hydroxyapatite, an apatite mineral known to have high sorption capacity, is a potential key process that could govern the speciation of $\mathrm{Cr}, \mathrm{Cu}$ and $\mathrm{Mo}$, but currently not accounted for in the model. Unfortunately, no adsorption database is currently available for hydroxyapatite, which hinders appropriate sorption quantification. The potential importance of this mineral is emphasized by the fact that this mineral's constituents were observed on site under favourable conditions for hydroxyapatite precipitation.

Taken together, our results aid in decreasing some of the knowledge gaps regarding geochemical controls of metal speciation within the Lake Baikal basin. We have also identified metals for which continued research on model development is needed. By evaluating the extent to which used state-of-the-art geochemical equilibrium model can deliver robust predictions of dominating processes governing metal speciation, we are in a better position for predicting the prevalence of various forms of these metals, for example in more downstream regions closer to Lake Baikal, where changing environmental conditions might be present. Given the often high metal loads and the understudied nature of non-acidic systems compared to acidic systems, increasing knowledge on processes controlling metal transport and fate in non-acidic waters is of high societal and ecological relevance.

Acknowledgments This research was funded by the Swedish Research Council Formas (Project No. 2012-790). This study is also part of the project Hydroclimatic and ecohydrological changes of the Lake Baikal drainage basin, financially supported by a travel grant from the Faculty of Science, Stockholm University. This work was additionally implemented under the support of the Russian-Mongolian biological expedition RAS-MAS with the Russian geographical society grant from the Russian Foundation for Basic Research (Project Nos. 12-05-00069-a, 12-05-33090). The analytical part of the work was partly supported by the Russian Scientific Foundation Project No. 14-17-00155.

Author contributions J. Thorslund performed the model simulations and manuscript preparation, with contributions from all the co-authors. J. Thorslund, J. Jarsjö and S.R. Chalov developed the research ideas, including field preparations, measurements and modelling approach. T. Wällstedt was responsible for the modelling aspects, including the parameter settings. C.M. Mörth was responsible for the analytical methods, sample handling and analysis. M.Y. Lychagin contributed to the geochemical interpretation.

\section{Compliance with ethical standards}

Conflict of interest The authors of this publication declare that there was no conflict of interest.

Open Access This article is distributed under the terms of the Creative Commons Attribution 4.0 International License (http://crea tivecommons.org/licenses/by/4.0/), which permits unrestricted use, distribution, and reproduction in any medium, provided you give appropriate credit to the original author(s) and the source, provide a link to the Creative Commons license, and indicate if changes were made.

\section{References}

AATA International Inc. (2008) Social and environmental impact assessment. Big Bend Placer Gold Mining Project, Mongolia. Denver, $\mathrm{CO}$

Ahmed IAM, Hamilton-Taylor J, Bieroza M, Zhang H, Davidson W (2014) Improving and testing geochemical speciation predictions of metal ions in natural waters. Water Res 67:276-291. doi:10. 1016/j.watres.2014.09.004

Alexeevsky NI, Chalov RS, Berkovich KM, Chalov SR (2013) Channel changes in largest Russian rivers: natural and anthropogenic effects. Int J River Basin Manag 11(2):175-191. doi:10. 1080/15715124.2013.814660

Almås AR, Lofts S, Mulder J, Tipping E (2007) Solubility of major cations and $\mathrm{Cu}, \mathrm{Zn}$ and $\mathrm{Cd}$ in soil extracts of some contaminated agricultural soils near a zinc smelter in Norway: modelling with a multisurface extension of WHAM. Eur J Soil Sci 58:1074-1086. doi:10.1111/j.1365-2389.2007.00894.x

Altansukh O, Davaa G (2011) Application of index analysis to evaluate the water quality of the Tuul River in Mongolia. J Water Resour Prot 03:398-414. doi:10.4236/jwarp.2011.36050

Antoniadis V, Alloway BJ (2002) The role of dissolved organic carbon in the mobility of $\mathrm{Cd}, \mathrm{Ni}$ and $\mathrm{Zn}$ in sewage sludgeamended soils. Environ Pollut 117:515-521. doi:10.1016/S02697491(01)00172-5 
Asgari G, Rahmani AR, Faradmal J, Seid Mohammadi AM (2012) Kinetic and isotherm of hexavalent chromium adsorption onto nano hydroxyapatite. J Res Health Sci 12(1):45-53

Balistrieri LS, Seal RR, Piatak NM, Paul B (2007) Assessing the concentration, speciation, and toxicity of dissolved metals during mixing of acid-mine drainage and ambient river water downstream of the Elizabeth Copper Mine, Vermont, USA. Appl Geochem 22(5):930-952. doi:10.1016/j.apgeochem.2007.02.005

Basu NB, Destouni G, Jawitz JW, Thompson SE, Loukinova NV, Darracq A, Zanardo S, Yaeger M, Sivapalan M, Rinaldo A, Rao PSC (2010) Nutrient loads exported from managed catchments reveal emergent biogeochemical stationarity. Geophys Res Lett. doi:10.1029/2010GL045168

Batbayar B, Karthe D, Pfeiffer M, von Tümpling W, Kappas M (2015) Influence of urban settlement and mining activities on surface water quality in northern Mongolia, Water and environment in the Selenga-Baikal basin. International Research Cooperation for an Ecoregion of Global Relevance. ISSN 1614-4716

Bazargan-Lari R, Zafarani HR, Bahrololoom MB, Nemati A (2014) Removal of $\mathrm{Cu}$ (II) ions from aqueous solutions by low-cost natural hydroxyapatite/chitosan composite: equilibrium, kinetic and thermodynamic studies. J Taiwan Inst Chem E 45:1642-1648. doi:10.1016/j.jtice.2013.11.009

Butler BA, Ranville JF, Ross PE (2008) Observed and modeled seasonal trends in dissolved and particulate $\mathrm{Cu}, \mathrm{Fe}, \mathrm{Mn}$, and $\mathrm{Zn}$ in a mining-impacted stream. Water Res 42(12):3135-3145. doi:10.1016/j.watres.2008.03.004

Butler BA, Ranville JF, Ross PE (2009) Spatial variations in the fate and transport of metals in a mining influenced stream, North Fork Clear Creek, Colorado. Sci Total Environ 407:6223-6234. doi:10.1016/j.scitotenv.2009.08.040

Caruso BS, Cox TJ, Runkel RL, Velleux ML, Bencala KE, Nordstrom DK, Julien PY, Butler BA, Alpers CN, Marion A, Smith KS (2008) Metals fate and transport modelling in streams and watersheds: state of the science and USEPA workshop review. Hydrol Process 22:4011-4021. doi:10.1002/hyp.7114

Chalov S, Zavadsky AS, Belozerova EV, Bulacheva MP, Jarsjö J, Thorslund J, Yamkhin J (2012) Suspended and dissolved matter fluxes in the upper Selenga River basin. Geogr Environ Sustain $5(2): 78-94$

Chalov S, Jarsjö J, Kasimov NS, Romanchenko AO, Pietroń J, Thorslund J, Promakhova EV (2015) Spatio-temporal variation of sediment transport in the Selenga River basin, Mongolia and Russia. Environ Earth Sci 73:663-680. doi:10.1007/s12665-0143106-Z

Chalov S, Thorslund J, Kasimov N, Aybullatov D, Ilyicheva E, Karthe D, Kositsky A, Lychagin M, Nittrouer J, Pavlov M, Pietron J, Shinkareva G, Tarasov M, Garmaev E, Akhtman Y, Jarsjö J (2016) The Selenga River delta—a geochemical barrier protecting Lake Baikal waters. Reg Environ Change. doi:10. 1007/s10113-016-0996-1

Chen SB, Ma YB, Chen L, Xian K (2010) Adsorption of aqueous $\mathrm{Cd}^{2+}, \mathrm{Pb}^{2+}, \mathrm{Cu}^{2+}$ ions by nanohydroxyapatite: single- and multi-metal competitive adsorption study. Geochem J 44(3):233-239. doi:10.2343/geochemj.1.0065

Christensen JB, Jensen DL, Christensen TH (1996) Effect of dissolved organic carbon on the mobility of cadmium, nickel and zinc in leachate polluted groundwater. Water Res 30:3037-3049. doi:10.1016/S0043-1354(96)00091-7

Chriswell B, Mokhtar MB (1986) The speciation of manganese in freshwaters. Talanta 33:669-677. doi:10.1016/00399140(86)80156-4

Corami A, Mignardi S, Ferrini V (2008) Cadmium removal from single- and multi-metal (Cd plus $\mathrm{Pb}$ plus $\mathrm{Zn}$ plus $\mathrm{Cu})$ solutions by sorption on hydroxyapatite. J Colloid Interface Sci 317(2):402-408. doi:10.1016/j.jcis.2007.09.075
Cory N, Andren CM, Bishop K (2007) Modelling inorganic aluminium with WHAM in environmental monitoring. Appl Geochem 22:1196-1201. doi:10.1016/j.apgeochem.2007.03.011

Destouni G, Persson K, Prieto C, Jarsjö J (2010) General quantification of catchment-scale nutrient and pollutant transport through the subsurface to surface and coastal waters. Environ Sci Technol 44:2048-2055. doi:10.1021/es902338y

Dzombak DA, Morel FMM (1990) Surface complexation modeling: hydrous ferric oxide, 1st edn. Wiley Interscience, Hoboken. ISBN-10: 0471637319

Feng Y, Gong JL, Zeng GM, Niu YQ, Zhang HY, Niu QY, Deng JH, Yan M (2010) Adsorption of Cd(II) and $\mathrm{Zn}(\mathrm{II})$ from aqueous solutions using magnetic hydroxyapatite nanoparticles as adsorbents. Chem Eng J 162(2):487-494. doi:10.1016/j.cej.2010.05. 049

Fytianos K (2001) Speciation analysis of metals in natural waters: a review. J AOAC Int 84:1763-1769

Gandhi MR, Kousalyab GN, Meenakshi S (2011) Removal of copper(II) using chitin/chitosan nanohydroxyapatite composite. Int J Biol Macromol 48:119-124. doi:10.1016/j.ijbiomac.2010. 10.009

GEMStat (2009) Global Water Quality Database. http://www. gemstat.org. Accessed 22 Oct 2013

Grosbois C, Schaefer J, Bril H, Blanc G, Bossy A (2009) Deconvolution of trace element (As, $\mathrm{Cr}, \mathrm{Mo}, \mathrm{Th}, \mathrm{U})$ sources and pathways to surface waters of a gold mining-influenced watershed. Sci Tot Environ 407(6):2063-2076. doi:10.1016/j.scito tenv.2008.11.012

Gustafsson JP (2010) Visual MINTEQ, version 3.0: a window version of MINTEQA2, version 4.0. http://www.lwr.kth.se/english/ OurSoftware/Vminteq

Gustafsson JP, Bhattacharya P (2007) Geochemical modelling of arsenic adsorption to oxide surfaces. In: Bhattacharya $\mathrm{P}$, Mukherjee AB, Bundschuh J, Zevenhoven R, Loeppert RH (eds) Arsenic in soil and groundwater environment. Trace metals and other contaminants in the environment, vol 9. Elsevier, Amsterdam, pp 159-206. doi:10.1016/S1875-1121(06)09006-7

Gustafsson JP, Dässman E, Bäckström M (2009) Towards a consistent geochemical model for prediction of uranium(VI) removal from groundwater by ferrihydrite. Appl Geochem 24:454-462. doi:10. 1016/j.apgeochem.2008.12.032

Gustafsson JP, Persson I, Oromieh AG, van Schaik JWJ, Sjöstedt C, Kleja DB (2014) Chromium(III) complexation to natural organic matter: mechanisms and modeling. Environ Sci Technol 48:17531761. doi:10.1021/es404557e

Hagedorn F, Kaiser K, Feyen H, Schleppi P (2000) Effects of redox conditions and flow processes on the mobility of dissolved organic carbon and nitrogen in a forest soil. J Environ Qual 29:288. doi:10.1023/A:1006398105953

Hayzoun H, Garnier C, Durrieu G, Lenoble V, Le Poupon C, Angeletti B, Ouammou A, Mounier S (2015) Organic carbon, and major and trace element dynamic and fate in a large river subjected to poorly-regulated urban and industrial pressures (Sebou River, Morocco). Sci Total Environ 502:296-308. doi:10.1016/j.scitotenv.2014.09.014

Hofmann J, Watson V, Scharaw B (2015) Groundwater quality under stress: contaminants in the Kharaa River basin (Mongolia). Environ Earth Sci 73:629-648. doi:10.1007/s12665-014-3148-2

Horowitz AJ (1991) A primer on sediment-trace metal chemistry, 2nd edn. Lewis Publishers, Chelsea. USGS water supply paper, 2277

Hudson-Edwards KA (2003) Sources, mineralogy, chemistry and fate of heavy metal-bearing particles in mining affected river systems. Miner Mag 67:205-217. doi:10.1180/ 0026461036720095

Inam E, Khantotong S, Kim KW, Tumendemberel B, Erdenetsetseg S, Puntsag T (2011) Geochemical distribution of trace element 
concentrations in the vicinity of Boroo gold mine, Selenge Province, Mongolia. Environ Geochem Health 33:57-69. doi:10. 1007/s10653-010-9347-1

Jarsjö J, Chalov S, Pietroń J, Alekseenko AV, Thorslund J (2016) Patterns of soil contamination, erosion, and river loading of metals in a gold mining region of Northern Mongolia. Reg Environ Change (Submitted)

Jung HB, Yun ST, Mayer B, Kim SO, Park SS, Lee PK (2005) Transport and sediment-water partitioning of trace metals in acid mine drainage: an example from the abandoned Kwangyang $\mathrm{Au}-\mathrm{Ag}$ mine area, South Korea. Environ Geol 48:437-449. doi:10.1007/s00254-005-1257-7

Karamalidis AK, Dzombak DA (2010) Surface complexation modeling: gibbsite. Wiley, London. ISBN 978-0-47058768-3

Karthe D, Chalov S, Borchardt D (2015) Water resources and their management in central Asia in the early twenty first century: status, challenges and future prospects. Environ Earth Sci 73:487-499. doi:10.1007/s12665-014-3789-1

Khazheeva ZI, Tulokhonov AK, Urbazaeva SD (2006) Distribution of metals in water, bottom silt, and on suspensions in the arms of the Selenga delta. Chem Sustain Dev 14:279-285

Landner L (2005) Speciation, mobility and bioavailability of metals in the environment. In: Metals in society and in the environment. Springer, pp 139-274. doi:10.1007/1-4020-2742-7_6

Lee YJ, Yun ST, Badarch M, Lee J, Ayur O, Kwon JS, Kim DM (2006) Joint research between Korea and Mongolia on water quality and contamination of transboundary watershed in Northern Mongolia. Korea Environmental Institute. Mongolian Nature and Environment Consortium

Lewis WM, Grant MC (1979) Relationship between stream discharge and yield of dissolved substances from a Colorado mountain watershed. Soil Sci 128:353-363

Lourino-Cabana B, Lesven L, Billon G, Proix N, Recourt P, Ouddane B, Fischer JC, Boughriet (2011) Impacts of metal contamination in calcareous waters of Deûle River (France): water quality and thermodynamic studies on metallic mobility. Water Air Soil Pollut 206:187-201. doi:10.1007/s11270-009-0095-8

Lychagin MY, Chalov SR, Kasimov NS, Shinkareva G, Jarsjö J, Thorslund J (2016) Surface water pathways of heavy metals and metalloids due to environmental change and human interventions in the Selenga River system. Environ Earth Sci (in review)

Macklin MG, Brewer PA, Hudson-Edwards KA, Bird G, Coulthard TJ, Dennis IA, Lechler PJ, Miller JR, Turner JN (2006) A geomorphological approach to the management of rivers contaminated by metal mining. Geomorphology 79:423-447. doi:10.1016/j.geomorph.2006.06.024

MCA (2011) Midterm report, Annex 4. Chapter 5.3. Water quality. http://en.mca.mn/file/545.shtml. Accessed 14 Apr 2011

Mighanetara K, Braungardt CB, Rieuwerts JS, Azizi F (2009) Contaminant fluxes from point and diffuse sources from abandoned mines in the River Tamar catchment, UK. J Geochem Explor 100:116-124. doi:10.1016/j.gexplo.2008.03. 003

Nystrand MI, Österholm P, Nyberg ME, Gustafsson JP (2012) Metal speciation in rivers affected by enhanced soil erosion and acidity. Appl Geochem 27:906-916. doi:10.1016/j.apgeochem.2012.01. 009

Österholm P, Åstrom M (2008) Meteorological impacts on the water quality in the Pajuluoma acid sulphate area, W. Finland. Appl Geochem 23:1594-1606. doi:10.1016/j.apgeochem.2008.01.011

Pandey M, Tripathi S, Pandey AK, Tripathi BD (2014) Risk assessment of metal species in sediments of the river Ganga. Catena 122:140-149. doi:10.1016/j.catena.2014.06.012

Parkhurst DL, Appelo CAJ (1999) User's guide to PHREEQC (version 2) 3195-2011, R program for speciation, batch reaction, one-dimensional transport, and inverse geochemical calculations. U.S. Geological Survey Water-Resources Investigations Report 99-4259

Persson K, Jarsjö J, Destouni G (2011) Diffuse hydrological mass transport through catchments: scenario analysis of coupled physical and biogeochemical uncertainty effects. Hydrol Earth Syst Sci 15:3195-3206. doi:10.5194/hess-15-3195-2011

Pfeiffer M, Batbayar G, Hofmann J, Siegfried K, Karthe D, HahnTomer S (2015) Investigating arsenic (As) occurrence and sources in ground, surface, waste and drinking water in northern Mongolia. Environ Earth Sci 73:649-662. doi:10.1007/s12665013-3029-0

Pietron J (2012) Modeling sediment transport in the downstream Tuul River, Mongolia. MSc thesis, INK, Stockholm University

Raposo JC, Olazabal MA, Madariaga JM (2004) Validation of chemical speciation model of inorganic arsenic in river waters with mobilisation processes. Chemical Speciation Bioavailability $16: 1-2,9-15$

Raymond PA, Saiers JE (2010) Event controlled DOC export from forested watersheds. Biogeochemistry 100(1-3):197-209. doi:10.1007/s10533-010-9416-7

Rudneva NA, Pronin NM, Rudneva LV (2005) Microelements and metals in the muscles of the Muskrat (Ondatra zibethica) from the Selenga River delta. Russ J Ecol 36:435-437. doi:10.1007/ s11184-005-0098-7

Sanches-Espańa JS, Pamo EL, Pastor ES, AndrÉs JR, RubÍ JAM (2006) The impact of acid mine drainage on the water quality of the Odiel River (Huelva, Spain): evolution of precipitate mineralogy and aqueous geochemistry along the ConcepciónTintillo Segment. Water Air Soil Pollut 173:121-149. doi:10. 1007/s11270-005-9033-6

Sauvé S, Hendershot W, Allen HE (2000) Solid-solution partitioning of metals in contaminated soils: dependence on $\mathrm{pH}$, total metal burden, and organic matter. Environ Sci Technol 34:1125-1131. doi:10.1021/es9907764

Schelker J, Eklöf K, Bishop K, Laudon H (2012) Effects of forestry operations on dissolved organic carbon concentrations and export in boreal first-order streams. J Geophys Res 117:G01011. doi:10.1029/2011JG001827

Shinkareva GL, Kasimov NS, Lychagin MY (2015) Heavy metal fluxes in the rivers of the Selenga basin, water and environment in the Selenga-Baikal basin. International Research Cooperation for an Ecoregion of Global Relevance. ISSN 1614-4716

Sjöblom Å, Håkansson K, Allard B (2004) River water metal speciation in a mining region - the influence of wetlands, liming, tributaries, and groundwater. Water Air Soil Pollut 152(1-4):173-194. doi:10.1007/s12665-012-1778-9

Sjöstedt C, Gustafsson JP, Köhler SJ (2010) Chemical equilibrium modeling of organic acids, $\mathrm{pH}$, aluminum, and iron in Swedish surface waters. Environ Sci Technol 44:8587-8593. doi:10.1021/ es $102415 r$

Smedley PL, Kinniburgh DG (2002) A review of the source, behavior and distribution of arsenic in natural waters. Appl Geochem 17(5):517-568. doi:10.1016/S0883-2927(02)00018-5

Smith R, Martell A, Motekaitis R (2003) NIST Critically Selected Stability Constants of Metal Complexes Database. Version 7.0. NIST Standard Reference Database 46. National Institute of Standards and Technology, US Department of Commerce, Gaithersburg

Stubblefield A, Chandra S, Eagan S, Tuvshinjargal D, Davaadorzh G, Gilroy D, Sampson J, Thorne J, Allen B, Hogan Z (2005) Impacts of gold mining and land use alterations on the water quality of central Mongolian rivers. Integr Environ Assess Manag 1:365-373

Sungur A, Soylak M, Ozcan H (2014) Investigation of heavy metal mobility and availability by the BCR sequential extraction procedure: relationship between soil properties and heavy metals 
availability. Chem Speciat Bioavailab 26:219-230. doi:10.3184/ $095422914 X 14147781158674$

Tack FMG, Verloo MG (1995) Chemical speciation and fractionation in soil and sediment heavy metal analysis: a review. Int $\mathrm{J}$ Environ Anal Chem 59(2-4):225-238. doi:10.1080/ 03067319508041330

Tarras-Wahlberg NH, Flachier A, Fredriksson G, Lane S, Lundberg B, Sangfors O (2000) Environmental management of small-scale and artisanal mining: the Portovelo-Zaruma goldmining area, southern Ecuador. J Environ Manag 65:165-179

Tessier A, Campbell PGC (1987) Partitioning of trace metals in sediments: relationships with bioavailability. Hydrobiologia 149(1):43-52. doi:10.1007/BF00048645

Thorslund J, Jarsjö J, Chalov SR, Belozerova EV (2012) Gold mining impact on riverine heavy metal transport in a sparsely monitored region: the upper Lake Baikal basin case. J Environ Monit 14:2780-2792. doi:10.1039/C2EM30643C

Tipping E (1994) WHAMC-a chemical equilibrium model and computer code for waters, sediments, and soils incorporating a discrete site/electrostatic model of ion-binding by humic substances. Comput Geosci 20:973-1023. doi:10.1016/00983004(94)90038-8

Tipping E, Rey-Castro C, Bryan SE, Hamilton-Taylor J (2002) Al(III) and $\mathrm{Fe}$ (III) binding substances in freshwaters, and implications for trace metal speciation. Geochim Chosmochim Acta 66:3211-3224

Tonkin JW, Balistrieri LS, Murray JW (2002) Modeling metal removal onto natural particles formed during mixing of acid rock drainage with ambient surface water. Environ Sci Technol 36:484-492

Tonkin JW, Balistrierib LS, Murrayc JW (2004) Modeling sorption of divalent metal cations on hydrous manganese oxide using the diffuse double layer model. Appl Geochem 19:29-53. doi:10. 1016/S0883-2927(03)00115-X
Törnqvist R, Jarsjö J, Pietroń J, Bring A, Rogber P, Asokan SM, Destouni G (2014) Evolution of the hydro-climate system in the Lake Baikal basin. J Hydrol 519:1953-1962. doi:10.1016/j. jhydrol.2014.09.074

USGS (2011) Lake Baikal's Selenga River Delta: biodiversity, conservation and sustainable development. Institute of General and Experimental Biology, Siberian Branch, Russian Academy of Sciences, Ulan-Ude. http://deltas.usgs.gov/rivers.aspx?river= selenga. Accessed 22 Oct 2013

Wällstedt T, Björkvald L, Gustafsson JP (2010) Increasing concentrations of arsenic and vanadium in (southern) Swedish streams. Appl Geochem 25:1162-1175. doi:10.1016/j.apgeochem.2010. 05.002

Weng L, Temminghoff EJM, Lofts S, Tipping E, Van Riemsdijk WH (2002) Complexation with dissolved organic matter and solubility control of metals in a sandy soil. Environ Sci Technol 36:4804-4810. doi:10.1021/es0200084

WHO (2006) Guidelines for drinking water quality, vol 1, 3rd edn. World Health Organization, Geneva

Yu CX, Peltola P, Nystrand MI, Virtasalo JJ, Osterholm P, Ojala AEK, Hogmalm JK, Astrom ME (2016) Arsenic removal from contaminated brackish sea water by sorption onto Al hydroxides and $\mathrm{Fe}$ phases mobilized by land-use. Sci Total Environ 542:923-934

Zandaryaa S, Aureli A, Merla A, Janchivdory L (2008) Transboundary water pollution in Baikal Lake basin: the role of surfaceground water interactions and groundwater. In: Basandorj D, Oyunbaatar D (eds) International conference "Uncertainties in water resource management: causes, technologies and consequences". IHP technical documents in hydrology, vol 1, pp 94-105

Zhao G, Wu X, Tan X, Wang X (2011) Sorption of heavy metal ions from aqueous solutions: a review. Open Colloid Sci J 2011:19-31. doi:10.2174/1876530001104010019 